\title{
DIE DOODSTRAF IN BYBELSE PERSPEKTIEF
}

\section{Inle:ding}

Die regverdiging van die doodstraf in Suid-Afrika bly 'n belangrike probleem. Gedurende die laaste jare het baie geskrifte daaroor verskyn, ${ }^{1}$ maar 'n regstreekse beroep op die leer van die Heilige Skrif het daarby agterweë gebly. Teoloë het wel aan die diskussie deelgeneem, ${ }^{2}$ maar hul het min melding van Skriftekste en uitleg van Skrifwoorde gemaak. ${ }^{3}$

In hierdie verhandeling wil ek probeer om hiermee te begin. Ek put uit die skat van die reformatoriese verlede en mak ook gebruik van meer resente gegewens.

'n Monnik het eenmaal, so word vertel, in sy Bybel die hexameter neergeskryf ,est liber hic, in quo invenit sua dogmata quisque', d.w.s. in hierdie boek vind elke ketter sy letter. Indien dit waar sou wees, sou die Skrif geen gesag hê nie en is by voorbaat ook hierdie studie nutteloos. Ons wil as uitgangspunt art. 2 van die Nederlandse Geloofsbelydenis neem, naamlik dat God Homself aan ons nog duideliker deur Sy heilige en Goddelike Woord geopenbaar het as in die skepping van die wêreld. Dit beteken nie dat wat hier volg bo kritiek verhewe is nie. Elke beroep op die Woord van God behoort egter ernstig geneem te word en die noodsaaklike toetsing moet uit dieselfde Woord en nie uit andere bronne wat die Woord loën of ignoreer nie, geskied.

Die werkingsfeer van die sesde gebod, Ex. $20: 13$ en Deut. $5: 17$

Die sesde gebod lui: Jy mag nie doodslaan nie.

Kort na die Tweede Wêreldoorlog met sy massale sinlose bloedvergieting het ' $\mathrm{n}$ studie verskyn van Johann Jakob Stamm. ${ }^{4}$ Daarin word die vraag gestel en beantwoord of hierdie verbod elke vorm van doodslag omvat en wat dan van die baie oorloë van Israel? of sou dit net betrekking op moord en arglistige doodslag hê?

Die skrywer stel die volgende: Die woord ,doodslaan', ràsach, soos dit in Ex. $20: 13$ en Deut. $5: 17$ voorkom, word in die Ou Testament 36 keer in wettekste en 10 keer in die geskiedkundige, profetiese en digterlike boeke aangetref. In die wet word dit gebruik waar dit gaan oor die asielstede as toevlugsoorde vir onopsetlike doodslaners, bv. Deut. $4: 41-43,19: 1-13$, Num. 35, Josua 20 en 21. Daar is sprake van ,doodmaak' sonder opset, waarvan voorbeelde genoem word. Vir opsetlike doodslag of moord gebruik die Bybelhebreeus ook die woord rãsach, bv. in Deut. $22: 26$,wanneer 'n man teen sy naaste opstaan en hom doodslaan' (vgl. Num. $35: 31$ ). Die woord rásach kom ook voor in Ps. $94: 6$ : ,Hulle (die goddelose) maak die weduwee en die vreemdeling dood en vermoor die wese'; Hosea $6: 9$ ('n priesterbende) ,pleeg moord op die pad na Sigem'; Jesaja $1: 2$ en 2 Kon. 6 : 32,1 Kon. 21 : 19 en die geregtelike moord op Nabot; Job 24 : 14, Hosea $4: 2$ en Jeremia $7: 9$. Uit Spreuke 22 : 13 volg dat hierdie woord in die algemeen beteken, doodmak'. 
Hieruit volg dat die verbod ,Jy mag nie doodslaan nie' nie net op moord betrekking het nie, maar ook op andere gevalle van onwettige doodslag sonder oorsaak en voorts op lewensberowing wat teen die gemeenskap gerig is en nie in sy diens staan nie.

Hierdie gevolgtrekking word versterk deur te let op die gebruik van Hebreeuse sinonieme harag en hemit. Die woord harag kom 165 keer voor en word gebruik in die volgende betekenisse: (1) doodmaak van 'n persoonlike teenstander, Genesis $4: 23,37: 20$ en 26, Exodus 2 : 14, Rigters $8: 19$ e.v., 1 Kon. $18: 12$ en 14; (2) vermoor van die teenstander, Genesis $4: 25,2$ Sam. $3: 30$ en $4: 11,2$ Kon. 9 : 31, Jeremia $4: 31$, Esegiël $28: 9$; (3) doodslag van 'n politieke vyand in of na die stryd, Josua $8: 24,9: 26,13: 22$, Rigters $7: 25$, $9: 45$ en 54, 1 Kon. $9: 16$, Amos $9: 4$; (4) dood van 'n persoon volgens die wet strafbaar, Exodus $32: 27$, Levitikus $20: 16$, Numeri 25 : 5, Deut. 13 : 10; (5) doodmaak van die kant van God, Exodus $13: 15$, Jeremia $27: 1$, Amos $4: 10,9: 1$, Ps. $78: 34,135: 10$, Klaagliedere $2: 21,3: 43$.

Die gebruik van die woord hemit kan in dieselfde groepe ingedeel word. Daaruit volg dat albei hierdie werkwoorde dieselfde inhoud het. Hul word gebruik om die feite te meld, soos by die voorgenome moord op Josef, Genesis $37: 18,20,26$; by die vermoording van Abner, 2 Sam. 3 : 30, 37; van Isboset, 2 Sam. 4 : 7, 11.

By vermelding blyk dat onder ràsach selde dieselfde verstaan word as onder harag en hemit. Miskien is die verskil weens die nog gebrekkige kennis van Hebreeus nie duidelik nie. Dié frekwensie waarin hulle gebruik word moet met die inhoud saamhang. Ràsach as die besondere werkwoord word seldsamer gebruik as die algemene harag en hemit. Hierdie vergelyking dui aan dat ràsach wel vir gebeurtenisse van die eerste twee bogenoemde groepe betekenisse gebruik word, maar nie vir die drie laastes nie. Die rede moet gesoek word in die verskil in die betekenis van die werkwoorde. Dit is nie toevallig nie dat ràsach nooit vir die doodslag in die stryd nie, slegs eenmaal vir doodslag van 'n skuldige en nooit vir vernietiging deur God gebruik word nie. Daaruit volg negatief, wat reeds positief gestel is, dat ràsach nie net betrekking het op gevalle van moord nie, maar ook op andere gevalle van onwettelike doodslag sonder oorsaak en voorts op elke teen die gemeenskap gerigte en nie in sy diens staande lewensberowing.

Die sesde gebod verbied dus nie elke vorm van doodslag nie, maar slegs doodslag in stryd met die belang van die gemeenskap. Boosaardige doodslag (moord) val dus onder daardie gebod. Tegelyk waarsku dit teen elke ligvaardige, onversigtige doodslag. In die laaste geval is daar ontkoming aan die doodstraf blykens Exodus 21 : $12-14$, ,Hy wat 'n mens slaan, dat hy sterwe, moet sekerlik gedood word. Maar as hy dit daar nie op toegelê het nie, maar God dit sy hand laat ontmoet het, dan sal Ek jou 'n plek aanwys waarheen hy kan vlug. Maar as iemand moedswillig teen sy naaste handel, om hom met lis dood te makk, moet jy hom van my altaar af wegneem, om te sterwe'. Die beskerming van die lewe word deur die strenge 
verbod van doodslag in Exodus $21: 12$, Levitikus $24: 17$, Genesis $9: 6$ en Numeri $35: 30$ e.v. gewaarborg.

In talryke andere gevalle was die doodstraf ook voorgeskryf, bv. by mishandeling en vervloeking van ouers, seksuele misdrywe, afgodery, Exodus 21 : 14-17, Levitikus 20, Deut. 13, $21: 18-23$. Op hierdie doodstraf was die sesde gebod nie van toepassing nie.

Ook oorlogshandelinge val buite die trefveld van die sesde gebod. Maar oorlogsmisdade is onderworpe aan profetiese kritiek, soos om gevange burgers met messe aan stukke te sny, Amos $1: 3$, deportasie van 'n bevolking, Amos $1: 9$, ,Brüderkrieg', Amos $1: 11$, oopsny van swanger vroue om grondgebied uit te brei, Amos $1: 13$, verbod van die taktiek van die verskroeide aarde, Deut. $20: 19,20$, plundering, Josua $7: 25$, die lyke van die vyande moes begrawe word, Josua $10: 27$ en Esegiel $39: 15$, krygsgevange vroue moes eerbaar behandel word, Deut. $21: 10-14$. Dit beteken nie dat die oorlog as sodanig goedgekeur word nie. Dit behoort tot die aardse sake wat in die heilstyd weggeneem sal word, Jesaja $2: 2-4,9: 5,6$, Sagaria $9: 10$.

Behalwe geoorloofde doodslag in die oorlogsvoering van Israel bestaan nog die voorskrif van die ban. Hierdeur word die vyand met al sy goed vernietig, aan menslike beskikking onttrek en aan God oorgegee, Josua $6: 17,21,7: 1,11-3,15,10: 1,35,37,39$ e.v., Levitikus 27 : 29, Deut. 7 : 1 e.v., 1 Sam. 15. In Deut. 7 word 'n streng toepassing van die ban voorgeskryf en volgens die boek Josua het die immigrerende volk dit ook dikwels in Kanaän toegepas. Aan die ander kant blyk uit die voortbestaan van die heidense volke in Kanaän, dat die toepassing van die ban nie volledig was nie. Baie verleiding tot afgodery en onsedelikheid was daarvan die gevolg.

Genoemde beperkinge van die sesde gebod is nie willekeurig of toevallig nie, maar blykens die gebruikte werkwoord duidelik die bedoeling, omdat ràsach 'n vorm van doodslag inhou, wat van doodslag volgens die wet en volgens oorlogsnoodsaak verskil.

Die doodstraf was in die Ou Testament dus wettig.

\section{Die betekenis van die Bybelse tradisie}

Onder baie Christene leef die opvatting dat die Ou-Testamentiese gebooie en voorskrifte hul geldigheid verloor het ${ }^{5}$ omdat Christus die Joodse tradisie afgewys het. Die Bybel leer egter duidelik die waarde en geldigheid van die tradisie, vgl. 1 Kor. $11: 21$ : ,Ek het van die Here ontvang wat ek (op my beurt) ook aan julle oorgelewer het ...', 2 Tim. $2: 2:$,Wat jy van my gehoor het onder baie getuies, vertrou dit toe aan getroue manne wat bekwaam sal wees om ook ander te leer'. Koning Josua herstel in 2 Konings die wet van Moses in ere, nadat dit vergeet was en soos juriste moontlik sou sê, deur non-usus afgeskaf was.

Christus verwerp egter die menslike tradisie. In Markus 7 : 9 e.v. sê Hy: ,Julle verstaan dit goed om die gebod van God opsy te sit en so julle oorlewering te onderhou'; $7: 13$ : ,So maak julle dan die woorde van God kragteloos deur julle oorlewering wat julle bewaar het en dergelike dinge van dieselfde aard doen julle baie. Lees ook 
Matt. 15 in hierdie verband.

Christus verwerp hier die leer van die rabbyneskole wat die vervulling van die wet van Moses tot die grootste religieuse prestasie van hul lewe gemaak het. Daarom sê Hy in Matt. 5 : 21: ,Julle het gehoor dat aan die mense van die ou tyd gesê is: Jy mag nie doodslaan nie' ens. Die rabbyne het deur uitlegkunde, kunsgrepe en mensebepalinge die wet pasklaar vir die eie tyd gemaak. Hul het byvoorbeeld verbied om die naam van God uit te spreek om ydel gebruik van daardie naam te voorkom. Christus het dit verwerp en daarop gewys wat die eintlike doel van die wet is. Matt. $23: 23$ : ,Wee julle, skrifgeleerdes en Fariseërs, geveinsdes, want julle gee tiendes van die kruisement en anys en koljander, en die swaarste van die wet laat julle na: die reg en die barmhartigheid en die trou'; Lukas 11 : 42: Julle verwaarloos die reg en die liefde tot God'.

Die Roomse Kerk het op soortgelyke manier beloftes van armoede van kloosterlinge geverg om te probeer voorkom dat hul sondig teen die agtste en tiende gebod. Die beding van rente is in die kanonieke reg verbied om oortreding van die Bybelse verbod van woeker te voorkom.

Christus was 'n herout en geen wettiese haarklower nie. Die Jode het hul speletjies met die wetsartikels gespeel en Christus verwerp om hul eie menslike tradisie in stand te hou.

Matt. 13 : 52 lui so: ,Daarom is elke skrifgeleerde wat 'n leerling geword het in die koninkryk van die hemele, soos 'n huisheer wat uit sy skat nuwe en ou dinge te voorskyn bring'. Hierdie waarheid geld vir gelowiges as teoloë en regsmense.

Dis nie profaan om hierdie woord regstreeks toe te pas op juriste van die praktyk en van die akademie nie. ,Nuwe dinge' want ons tyd versnel en ons moet rekening hou met die regsbehoeftes van vandag en die toekoms. ,Ou dinge' want ons moet bewaar en onderhou wat ons as Bybelse tradisie ontvang het ook t.o.v. ons positiewe reg. ${ }^{6}$ Ek gaan dus daarvan uit, dat die tien gebooie nog aktueel is vir vandag.

\section{Calvyn oor sagmoedigheid in die positiewe reg}

Die opvatting van Calvyn omtrent die doodstraf moet ons in die geheel van sy oortuiging as regsman en teoloog beskou.

Calvyn sê dat roof van die lewe roof van 'n heiligdom (sacrilegium) is. Reeds in sy Seneca-kommentaar het Calvyn die aequum et bonum teen die strenge reg as norm gestel om die bepalings van die strenge reg te matig. God verlang van ons om na die beste reg sy eise te vervul. Die straf van die owerheid staan in diens van die liefde. Dis 'n sonde teen die mensheid en sy instellings wanneer onder voorwendsel van humaniteit barmhartigheid vir die skuldige geëis word. Die ongestraf laat van een misdadiger kan baie onskuldiges in die verderf bring. Daarom moet die owerheid die wet streng laat regeer en standvastig en grootmoedig bly, veral waar dit om uitgesproke vyande van God gaan. Die owerheid moet daarby egter alle wraaksug en hartstog laat vaar en met die skuldige meelyde hê. 
Daar is egter ook gevalle waarin mens die strenge reg nie mag gebruik nie. Daar bestaan 'n , wet van billikheid' wat t.o.v. die skuldige wat dit ,waardig' is versigtig toegepas kan word. Dit word aan die goeddunke van die owerheid oorgelaat om wanneer die toestand van die staat verander en veral in oorlogstyd nuwe wette te maak. In die belang van menslikheid moet strenge wetgewing ingevoer word in omstreke wat deur die misdadigers geteister word. Die inhoud van die nuwe wette rig hom na die lewenswerklikheid en nie na denkkategorieë nie.

Calvyn reken op voetspoor van Cicero en die Romeinse reg onveranderlike billikheid tot die blywende wese van elke positiewe wet. Billikheid is deel van die positiewe reg. Ook in die strafreg gaan Calvyn van die Romeinse reg uit. Hy verset hom egter teen bepalings soos die patria potestas wat die reg oor lewe en dood van die kinders inhou. Hy wys ook die reg van die vader of eggenoot van 'n onteerde vrou om die verleider te dood af en eweneens die potestas vitae ac necis oor slawe. Die toetsing van Romeinse en Mosaiese reg moet geskied volgens die reël van die liefde. ${ }^{8}$

Geregtigheid is om die onskuldiges te beskerm, te red en te verlos. Reg is om die vermetelheid van die goddelose te weerstaan, hul geweld te onderdruk en om hul misdade te bestraf. Maar dan roep hierdie punt 'n moeilike vraag op. Indien die wet van God Exodus $20: 13$, Deut. 5 : 17, Matt. $5: 21$ al die Christene verbied om te dood en die profeet Jesaja $11: 9,65: 25$ verbied om iemand in die kerk leed of skade aan te doen, hoe kan die owerheid dan vroom wees en tegelyk ook bloed stort? Calvyn antwoord met verwysing na Rom. $13: 14$, Exodus $2: 12,32: 17,1$ Kon. $2: 5$, Ps. $101: 8$ en 45: 8 dat Moses en Dawid deur wraak uit te oefen wat God hul opgedra het, hul hande geheilig het. Wanneer hulle hul van die straf sou onthou het, sou hulle hul hande besoedel het. Met verdere verwysing na Spreuke $16: 12,20: 8,20: 26,25: 4,5,17: 15,17: 11$ en $24: 4$ stel hy: Indien dit die ware geregtigheid van die konings is om die skuldiges en goddeloses met die getrokke swaard te vervolg, sal hulle hul aan die grootste goddeloosheid skuldig maak, wanneer hulle hul swaard in die skede steek en hul hand rein hou van bloed, terwyl die bose mense intussen misdadig met moord en doodslag woed; doen weg met die regbank waar barse en wrede ruheid die aangeklaagdes verpletter; die vorste het vernaamlik sagsinnigheid as allerbeste raadgewer en bewaarder van hul troon nodig, Spreuke $20: 28$, om billik te kan oordeel.

Op hierdie twee dinge egter moet 'n owerheidspersoon let: hy moet nie deur al te grote gestrengheid meer wond as genees nie en ook nie bygelowig jaag na sagsinnigheid en tog by 'n baie wrede mensliewendheid uitkom nie alwaar 'n slappe toegeeflikheid tot verderf van baie lei nie. Dit is seker swaar om te leef onder ' $n$ vors by wie niks geoorloof is nie, maar dit is nog baie erger onder ' $n$ vors by wie alles veroorloof is. ${ }^{9}$ 


\section{Guido de Brès oor die roeping van die owerheid teenoor die leer van die Wederdopers}

Hy handel in die deur hom opgestelde Nederlandse Geloofsbelydenis oor die amp van die owerheid ${ }^{10}$ en sê dat onse goeie God die swaard aan die owerheid gegee het om die bose te straf en om die eerbare mense te beskerm. Die doodstraf word nie as sodanig in hierdie belydenis genoem nie, maar saaklik word dit daarin wel geleer. ${ }^{11}$ Hierdie predikant het self die doodstraf ondergaan. In sy laaste woorde voor hy aan die galg gehang is op 35-jarige leeftyd in 1567 het hy staande op die trap van die galg die volk vermaan om hul owerheid gehoorsaam te wees. ${ }^{12}$ Hoewel hy self ten onregte die doodstraf ondergaan het, het hy in sy ,Wortel ende Oorspronck' ${ }^{13}$ uitvoeriger as Calvyn in sy "Institusio' die reg en die plig van die owerheid om die doodstraf reg te gebruik uit die Woord van God verdedig. Hy sê: Die bewering dat die magistraat die bloed van die kwaaddoeners nie behoort te vergiet nie, is heeltemal vals en in stryd met die instelling van God. Hy verwys na Genesis $9: 6,48: 22$ en 38 : 24, Exodus 21 : 12, 14, Lev. $24: 17$, Num. $35: 17,31,2$ Sam. $1: 25,1$ Kon. $2: 5,6$, Ps. 101, Spreuke $10: 8,26,17: 15,24: 24$, 25 : 4. Die doodslaner moes gedood word omdat hy, sê die Here, die aardryk van u woning nie besmet nie, Num. $35: 31,33$. Wie barmhartiger as God wil wees, is vervloek, Jeremia $48: 10$.

Die Wederdopers sê dat die Ou Testament afgeskaf is. Maar die politieke regering is geen figuur of skadu wat moes eindig by die koms van Christus en wat met die seremoniële dinge gelyk gestel kan word nie. Dit is 'n noodsaaklike instelling om die vrede in die Kerk van die Here te bewaar.

Die Wederdopers het die magistrate moordenaars genoem omdat hul bose mense volgens die bevel van die Here doodmaak. De Brès skryf hulle standpunt toe aan 'n bose gees. Op sterkte van 2 Petrus $2: 1,10$, Judas : 8 en Hebreërs $11: 32$ moes mens die doodstraf van bose mense en die gebruik van die swaard deur die rigters as 'n werk van die geloof beskou. Net soos persone in die kerk van Israel in 'n ware geloof hul ryk kon verdedig en bewaar, so mag Christelike konings en magistrate deur dieselfde geloof dieselfde doen. Die magistrate oefen die geregtigheid van God uit wanneer hul die boosdoeners straf, want hul doen dit nie vanweë hul private en partikuliere gesag nie, maar kragtens die bevel en instelling van God.

Christus leer in Matt. 5 : 39 nie dat daar geen magistraat nodig is nie, maar verwerp die valse uitleg van die wet deur skrifgeleerdes en Fariseërs. Mense mag nie vryelik onreg wreek nie omdat God dit in die wet verbied het en die mens dit aan die owerheid moet oorlaat, Exodus $21: 24$, Lev. $19: 17,24: 20$, Deut. $19: 21$. Die verbod van Christus aan Petrus in Matt. 26 : 51 (ook t.o.v. Lukas 9 : 53, 2 Kor. $10: 4$ ) om die swaard te trek, het nie betrekking op 'n magistraat nie. 
Moet ons wag op die berou van die misdadigers?

De Brès sê dat almal wat volgens die bevel van God die boosdoeners met die dood gestraf het dit nie gedoen het nie (ook nie Petrus t.o.v. Ananias en Saffira nie). Juis deur die doodstraf kan mense tot berou kom, soos die moordenaar langs die kruis van Christus. Die Wederdopers se opvatting is 'n doodsvyand van die algemene welvaart in Munster of Amsterdam? Indien die owerheid dan die swaard sou bêre, sou hy God versoek. Natuurlik wou Guido de Brès hiermee nie die owerheid tot wreedheid aanspoor nie, maar net wys op sy las en plig volgens sy roeping.

\section{Idzardus Nicolai oor die Christen en die wêreldlike swaard ${ }^{14}$}

God het die owerheidsamp ingestel en daaraan die swaard toevertrou om die bose dade te straf, Josua 7 , Deut. $19: 10,13,20$. Onder alle nasies is van ouds af enige growwe sonde met die dood gestraf, Genesis $9: 6,38: 24$. Aan Moses het God wette gegee waarvolgens verskeie bose dade en gruwels met die dood gestraf moes word, Exodus $21: 22$ e.v., Deut. $19: 13,21$ en God het hul swaar gestraf indien hulle dit versuim, I Samuel 15. Christus het hierin geen verandering gebring nie, Rom. $13: 3,4$.

Die swaard van die geregtigheid kan die beste deur regverdige Christene bedien word. Die doodstraf is ' $n$ algemene ordening onder alle volke en vir alle tye, ook vir die Christelike volke. Matt. $5: 39^{15}$ leer nie anders nie, want Christus het nie gekom om Moses en die profete te ontbind nie, maar om hul te vervul. In Matt. $13: 28-30$ wys die ontsien van die onkruid tussen die tarwe op verdra van slegte mense in die kerk solank hul sonde nie openbaar is nie (vgl. Matt. $18: 17,1$ Kor. 5). Dit gaan hier nie om 'n toleransie wat 'n magistraat sou moet beoefen nie.

Die sagmoedigheid, lydsaamheid en barmhartigheid wat mense jeens hulle vyande moet hê (Job $31: 29,30$, Spreuke $20: 22$, $24: 17-19,25: 21$, Lev. $19: 8$ ) sluit nie uit dat hul billik toornig moet wees om te straf volgens hul roeping nie. Christus self was 'n voorbeeld van sagmoedigheid, lydsaamheid, liefde en barmhartigheid (Matt. $11: 28,29,1$ Petrus $2: 21,23$, Joh. $15: 12$ ) maar Hy het tog die skrifgeleerdes en Fariseërs in erns bestraf (Matt. 23). Die apostels het ook met heilige ywer getoorn (Hand. $5: 3$ e.v., $8: 20$, $13: 10,11$, Gal. $5: 12,2$ Tim. $4: 14)$. Ja, die geeste in die hemel roep om vergelding (Openb. $6: 10$ ).

Dus sal ' $n$ magistraat, gelowig of ongelowig, na die algemene amp van mense of Christene wel sagmoedig, lydsaam, barmhartig en gewillig wees om sy naaste te vergeef. Wanneer God of die Justisie en die algemene welvaart straf vir die misdade eis, sal hy volgens sy besondere roeping bereid wees om die bose te straf. Nogtans sal hy in sy hart meelyde met die ellendige hẽ, hoewel hy deur sy werk verhinder word om dit te bewys.

Die Wederdopers spot en sê dat volgens hierdie leer die een broeder, wat magistraat is, soms 'n ander broeder om die lewe bring. 
Hul verwyt egter God, die opperste regter, wat dit van die begin af so beveel het. Hul moet primêr in die verhouding van regter en misdadiger aangedui word en nie primêr in 'n verhouding van broederskap nie.

Daar is ook persone wat sê dat die Christene nie met die wêreldlike swaard gemeenskap mag hê nie (Joh. $17: 16$, Fil. $3: 20$ ). Die Christene het soos alle mense deel aan wêreldse dinge soos voeding, kleding, huwelik, koopmanskap. Die apostel waarsku net teen misbruik daarvan (1 Kor. $7: 31$ ). Die wêreldlike swaard word dus aan Christene nie verbied nie.

Ander mense sê: Christus het die owerspelige vrou nie verdoem nie (Joh. $8: 11$ ). Maar Christus het die toepassing van die wet van Moses ook nie verbied nie. Hy het net gesê: ,Laat die een van julle wat sonder sonde is, as eerste 'n klip op haar gooi' (Joh. $8: 7$ ). Daarmee het Christus die skynheiligheid van die Fariseërs bestraf. Hierdie woorde leer eerder dat iemand die doodstraf mag toepas indien hy self van die bepaalde sonde vry is.

Ten laaste word gesê dat indien die misdadiger boetvaardig is, moet die misdaad hom vergeef word of hy moet kans kry om hom te bekeer. Dus die doodstraf is altyd verkeerd. Die Ou Testament leer egter dat die misdadiger die doodstraf nie as 'n kind van God en lidmaat van Christus ondergaan nie, maar as lid van die menslike geslag en van die burgerlike maatskappy. Die onboetvaardige word deur die doodstraf nie van die moontlikheid van berou beroof of aan die duiwel opgeoffer nie. As God nie verder tyd vir berou wil gun nie, kan God se dienaars niemand daarvan beroof nie. Indien die mens hom nie deur die oordeel van God tot bekering laat beweeg nie, sal niks hom daartoe kan beweeg nie.

\section{H. A. van der Valk oor die eenheid van die Skrif ${ }^{16}$}

Ook hy redeneer dat Genesis $9: 6$ vir alle mense geld en dat God hierdie bevel nooit ingetrek het nie. In Joh. $10: 35$ word duidelik gesê dat die Skrif nie gebreek kan word nie, maar 'n ondeelbare eenheid vorm. Christus het hom gekeer teen die wetsopvatting van die skrifgeleerdes, wat gemeen het dat hul met die daad kon volstaan, al ontbreek die gesindheid (Lukas $18: 9-14$ ). Hy sê herhaaldelik ,Julle het gehoor' of ,daar is gesê' en ,maar Ek sề vir julle' omdat Hy hom nie teen die Mosaïese wet nie, dog teen die Joodse tradisie keer. Hy dreig met die helse vuur (Matt. 25 : 30, Markus 9 : 43-48, Openb. $19: 20,20: 10,14,15)$, 'n erger straf as die doodstraf onder mense en bevestig sodoende die handhawing daarvan. Hy verbied Petrus om die swaard te gebruik, Joh. 18 : 11, omdat Hy nie wêreldlike geweld in diens van Sy koningskap, wat nie van hierdie wêreld is nie, wil neem nie. ${ }^{17}$ Matt. $26: 55$ erken implisiet die owerheidsplig om teen moordenaars met geweld op te tree (Lukas 19:27 en Matt. $25: 30$ ).

Jesus het aan die een kant benadruk dat die keiser regeer by die grasie van God, Joh. $19: 11$, en aan die ander kant dat elke owerheidspersoon in alles aan God verantwoording skuldig is. In 
Openb. 6 : 9-11 word geen persoonlike wraak gevra nie, maar toepassing van Goddelike geregtigheid. Vroeër is in Nederland die aand voor en die môre van die teregstelling aan die veroordeelde Ps. 88 voorgelees. In hierdie psalm is nie 'n ligstraal nie. Dit is nog droefgeestiger as Ps. 77. Die digter sê in Ps. 88 dat God sy vyand is en dat hy onder die reg van God verkeer. Die sterwende sanger bly egter tog besig om te bid. Dit is wat die doodstraf ons leer: eers God se reg, daarna Sy ewige genade.

\section{Die Rome.ns-Hollandse Reg en die Skrif}

Die Hoge Raad van Holland het insake 'n beroep op toepassing van die doodstraf volgens Exodus $22: 16$ en Deut. $22: 29$ geoordeel dat die Ou-Testamentiese wette geen deel van die positiewe RomeinsHollandse reg uitmaak nie. ${ }^{18}$ Laasgenoemde bedreig owerspel volgens die Politieke Ordonnantien net met 'n ,privatie van officie, ende een boete van hondert guldens'.19

In 'n geval in 1651 waar doodslag in dronkenskap gepleeg is, is ondanks teenoorgestelde adviese van advokate, howe en die State van Holland die doodstraf tog toegepas. Die opinie van verskeie gereformeerde teoloë, wat o.a. met beroep op die dronkenskap van Lot betoog het dat volgens die billikheid en goddelike reg die sonde van doodslag in dronkenskap gepleeg nie so swaar is, dat dit met die dood gestraf sou moet word nie, is deur die Magistraat van Delft verwerp. ${ }^{20}$

\section{Hugo de Groot oor die doodstraf}

In sy beroemde werk, De jure belli ac pacis' ${ }^{21}$ word oor straf gehandel. De Groot merk op dat straf in die algemeen beteken 'n lyde wat opgelê word weens 'n bose daad. Hy verwys na Augustinus wat sê dat elke straf, indien regverdig, 'n straf vir sonde is. Volgens die Goddelike reg in Deut. $25: 2,3$ moet die regter die skuldige met 'n aantal slae ooreenkomstig sy skuld laat slaan, maar met nie meer as veertig nie. ' $n$ Skuldige behoort nie gestraf te word deur 'n persoon wat net so skuldig is as hy nie (Joh. $8: 7$, Rom. $2: 22$, Rom. $2: 1$ ). Seneca het dieselfde opvatting gehuldig. Volgens Plato dien die straf die kwaaddoener ten goede.

Die argumente kan nie t.o.v. die doodstraf geld nie, behalwe wanneer die negatiewe tot die teenoorgestelde positiewe waarde beredeneer word. Hy verwys na Markus $14: 21$, waar Christus sê dat dit vir sommige beter sou gewees het om nooit gebore te gewees het nie en lei af dat dit vir 'n geharde kwaaddoener beter is om te sterf as om te leef, wanneer dit seker is dat hy by lewe nog slegter sou word. Seneca het ook gesê dat dit vir sommige in hul eie belang is om te sterf. Simson maak daarop aanspraak dat hy onskuldig sal wees indien hy die Filistyne kwaad aandoen, omdat hy as rigter hul kwaad vergeld (Rigters $15: 3$ ).

Volgens De Groot is die wet van die Evangelie in hierdie saak duidelik. Die Hebreeuse wet het nie net verbied om jou broeder te 
haat nie (Lev. $19: 17$ ), maar ook vriendelikheidsbetoon aan vyande voorgeskryf (Ex. 23 : 4, 5). Die Evangelie het die begrip ,naaste' uitgebrei tot alle mense (Matt. $5: 44$ ). Christus het die Ou-Testamentiese strawwe nie afgeskaf nie. Indien die onderrig van Christus in ooreenstemming kon wees met die wet van Moses in sover as die laaste selfs die doodstraf voorskryf, dan kan dit ook in ooreenstemming wees met menslike wette wat die goddelike wet in hierdie opsig naboots.

Om die teenoorgestelde standpunt te verdedig beroep sommige mense hul op die buitengewoon milde liefde van God in die Nuwe Verbond wat die mense, selfs owerhede, sou moet navolg. De Groot gee dit tot 'n sekere mate toe, maar beperk die toepassing. In die Nuwe Verbond bewys God genade t.o.v. sondes wat teen die alleroudste wet begaan is voor die mense van die Evangelie kennis gehad het (Hand. $17: 30$, Rom. $2: 25$, Hand. $13: 38$, Hebr. $9: 15$ ). Maar die sondes wat met kennis van die Evangelie begaan is met minagting vir die wet, word met 'n baie ernstiger straf bedreig as wat Moses voorgeskryf het (Hebr. $2: 3,10: 29$, Matt. $5: 21,22$, 28). Dis nie net in die ewige lewe nie, maar ook in hierdie lewe dat God dikwels sulke sondes straf (1 Kor. 11 : 30). En vergewing van sulke sondes word net ontvang as iemand in sielesmart self om straf vra (2 Kor. $11: 3,2$ Kor. $2: 7$ ).

Berou alleen maak nie straffeloos nie, vgl. die voorbeeld van Dawid. Dit is bowendien vir mense nouliks moontlik om te besluit of daar waaragtig berou is. God is in staat om die straf van die ewige dood op te hef al word die sondaar met die tydelike dood deur middel van 'n magistraat gestraf. Die doodstraf verhinder nie die moontlikheid en tyd vir berou nie. Die doodstraf is dus deur Christus nie verbied nie. Nietemin sal dit tot 'n mate vir Christelike regeerders profytlik wees om die doodstraf te verander tot 'n vonnis van harde arbeid.

De Groot sê voorts ${ }^{22}$ dat mens die boosheid van die wêreld slegs kan verhinder deur middel van skrik wanneer leed aan die misdadiger toegebring word.

\section{S:mon van Leeuwen se opvatting oor die doodstraf ${ }^{23}$}

Die swaard van die geregtigheid het God aan die owerhede gegee om met ' $n$ gematigde straf te wreek. Dit is 'n voorbeeld om die kwaaddoener wat kwaad doen of wou doen, af te skrik. As afskrikmiddel ag hy selfs die doodstraf in geval van diefstal soos by die Romeine geregverdig. Hy sê dat die Ou-Testamentiese reëls weens die wêreldlike veranderings van mense, tye, plekke, persone ens. nie as onveranderlik beskou moet word nie en dat hul ook in die Ou Testament nie onveranderlik was nie. Exodus $22: 1$ noem 'n vyfvoud by diefstal in plaas van 'n viervoud. In Spreuke $6: 31$ is sprake van 'n sewevoud. Josua $7: 25$ vermeld steniging in geval van diefstal. In 2 Sam. $12: 5$ spreek Dawid die doodstraf uit oor die dief van 'n ooilam.

Volgens die Romeins-Hollandse reg noem Van Leeuwen die doodstraf verplig in geval van moord $(34)$, verkragting $(36,2)$, 
openbare huisbraak $(36,3)$, ontvoering van 'n vrou $(36,4)$, brandstigters en deurstekers van dyke, veediefstal $(36,5)$, sodomie en bestialiteit $(37,10)$. Die regters het diskresie in geval van crimen laesae majestatis $(33,2)$, godslastering - doodstraf by uitsondering $(33,5)$, kerkroof, meestal doodstraf $(33,6)$, valse munt $(33,12)$, oproermakers en bedrywers van openbare geweld $(36,1)$. Hieruit blyk dat die Romeins-Hollandse reg gematigder was as die Romeinse Reg.

In sy Proces Crimineel ${ }^{24}$ vermeld Van Leeuwen dat in gewigtige en twyfelagtige sake die advies van vername onpartydige regsgeleerdes gevolg moet word, wat algemene praktyk in alle lande was. Dit kom ooreen met die burgerlike wet van Moses in Deut. $17: 8-10$. Die Levitiese priesters was die uitleggers van die wet en in ons tyd is hul die regsgeleerdes. Soos 'n regter niemand buite die wet om mag straf nie, so mag hy ook die vaste straf van die wet nie verminder nie, tensy die omstandighede die feit self verminder, omdat die remissie en die vermindering van straf net aan die hoogste mag en nie aan die regter toekom nie.

Die regter moet besef dat aan hom die bevoegdheid gegee is om afgesien van eie wense te doen wat die wet en sy gewete aan hom gebied. In twyfelagtige sake moet die ligte en sagte kant die swaarste weeg. Die algemene reël is dat wanneer geen mens gesterf het nie daar ook geen doodstraf mag plaasvind nie. Hierdie Romeinse wet het sy oorsprong in Exodus $21: 23,24,21: 12,14$ en 19.

Mag die wil as die daad gestraf word? Die regter mag oordeel en hoef nie altyd die doodstraf op te lê nie. Sommige mense sê dat uit Exodus 21 : 14 volg dat die wil as die daad geneem moet word. Van Leeuwen wil egter hierdie Bybelteks nie in abstracto neem nie, maar as deel en uitleg van wat in vers 12 voorafgaan (vgl. Lev. $24: 17)$. Vers 13 gee die reg aan die onskuldige om te vlug. In vers 18,99 en 22 vind ons dieselfde beginsel, waaruit volg dat die wil en voorneme sonder 'n daad wat daarop gevolg het, nie met die dood gestraf mag word nie (Lev. $24: 15$, Ex. $21: 13,14$, Lev. $24: 20-22$ ). Die vertaling van die Vulgaat, die Oud-nederlandse, dié wat in 1551 aan Eduard VI van Engeland aangebied is, dié van Nicolaas de Lyra en die Septuagint wys op dieselfde. Net in die uitsonderingsgevalle wat die wet noem, mag die wil as die daad gestraf word, soos in geval van landverraad en prinsemoord, moord en nagdiewery, verkragting, roof, hulp of bystand by ontvoering van 'n vrou en vadermoord.

\section{Ulric Huber oor straf en vergelding ${ }^{25}$}

Huber beskou straf as vergelding vir misdaad. Die magistraat lê straf op met die oog daarop om ander mense af te skrik. Die Goddelike wet beveel duidelik dat die vaders nie vir die kinders en die kinders nie vir die vaders gedood mag word nie; elkeen moet vir sy eie sonde gedood word (Deut. $24: 16$, Eseg. $18: 20,2$ Kon. $14: 6,2$ Kron. $15: 5$ ). Hy diskusseer ook oor Exodus $20: 5$, maar bevind dat hierdie saak miskien bo die regsgeleerdheid uitgaan. 
Kritiek op strafteorie wat die maatskaplike orde wil handhaaf

De Savornin Lohman meen dat daar in die kriminologie baie strafteorieë los van die Bybelse waarheid ontwikkel het. Daartoe behoort die teorie dat straf nodig is om die maatskaplike orde in stand te hou en derhalwe die doel dat straf tot afskrikking, verbetering en/of voorkoming van herhaling van die misdaad dien. Volgens hierdie opvatting is straf dwangmiddel. Die doodstraf word hiervolgens net met die oog op die verdediging van die maatskaplike orde gehandhaaf. Hy oordeel dat hierdie ongeloofsleer die toeneming van misdaad en minagting van die menslike lewe veroorsaak. Straf geskied mos net uit behoefte aan handhawing van menslike instellings. Teen hierdie opvatting kom sommige gewelddadig in opstand en hulle is bereid om martelare van die ,reg' te word. Die strafregter is dan immers niks anders as die arm van die sterke nie.

God het egter die orde onder die mense gestel. Verbreking van hierdie goddelike orde is sonde teen God. Die regters is gesagsdraers van God, wat 'n hoë roeping vervul en volgens die ordening van God deur toevoeging van leed verbreking van hierdie orde met straf vergeld, die volk ten goede. Wetgewing reël in besonderhede die beginsels van God se orde. Daarby wys dit aan op watter wyse die juiste vergeldingsmaat volgens die beginsel ,oog om oog' in praktyk gebring word.

Ongelowiges lees in hierdie vergelding wraakoefening en verwar goddelike toorn met die menslike. Hulle veroordeel dan die menslike ,wraakgierigheid' in skerp taal. Die opvatting dat ons moet toorn volgens God se wet teen die misdaad, al bring dit vir ons ongemak, word deur die meeste strafregsleraars en wetgewers as heeltemal verouderd en verwerplik beskou.

\section{Die doodstraf is misbruik}

Die doodstraf is gruwelik misbruik. Die doodstraf weens diefstal word deur die Woord van God nie geleer nie. Dink maar aan die grootspraak en wraak van Lameg voordat die doodstraf ingestel is (Gen. $4: 23-24$ ). Die Here veroordeel dit in Genesis $9: 6$. Net hy wat die bloed van 'n mens vergiet, sy bloed sal deur die mens vergiet word. Hierin word die wraakgedagte afgewys. Die Christelike opvatting is dikwels verkeerd toegepas omdat afskrikking te veel en vergelding te min benadruk is. Om 'n lewe te neem met die doodstraf tot beskerming van eiendom is in stryd met die Woord van God. As die doodstraf nie op die Woord van God berus nie, bestaan daarvoor geen grond nie. Die subjektiewe bedoelings van die dader moet buite beskouing bly. So regverdig 'n beroep op die politieke aard van 'n misdryf, bv. terrorisme, nie die doodslag of moord nie.

In sommige lande en buitengewone tye, bv. tydens oorlog of ondermyning van die openbare orde, is harder strawwe nodig. Genesis 9:6 is nie alleen 'n reg nie, maar ook 'n plig van die owerheid, wat algemeen en altyd geldend is. Ons mag die woorde 
van hierdie gebol, wat nie spesiaal vir Israel as volk afgekondig is nie, geen geweld aandoen nie. ${ }^{20}$

\section{D e beginsels van Genesis $9: 6$}

Hierdie teks wat deur baie as beslissend vir die handhawing van die doodstraf in geval van moord beskou word, moet ons in die konteks van Genesis $8: 21-9: 17$ beskou. Die verklaring daarvan moet objektief wees as openbaring van God en in verband met die Here Christus. ${ }^{27}$

Die woorde ,Hy wat die bloed van 'n mens vergiet, sy bloed sal deur die mens vergiet word', is deur God tot Noag gespreek na die ondergang van die eerste wêreld. Die aarde was leeg en moes weer bevolk word. God doen nou aan Noag die belofte, dat waters nie meer 'n vloed sal word om alle vlees met inbegrip van die diere te verdelg nie (Gen. $9: 15$ ), maar dat normale afwisseling in die natuur sal plaasvind (Gen. $8: 22$ ). Hierdie ,natuurverbond' is 'n fase in die genadeverbond, waarin God die natuur ondergeskik maak tot bou van die hemelstad.28 Om die hemelstad te bevolk uit agt mense kom die positiewe gebod dat die mens vrugbaar moet wees en vermeerder en die aarde moet vul (Gen. 9:1). Dit is 'n doodsonde om hierdie goddelike opdrag te verhinder deur mensebloed te vergiet. Wie dit doen, moet met die dood gestraf word (Gen. $9: 6$ ). Die negatiewe gebod is nodig om genoemde positiewe doel te verwesenlik. ${ }^{2 \theta}$

\section{Die wetgewing van Sinai}

Hierdie wetgewing was allereers bestemd vir die volk van Israel. Die gevalle waarin die doodstraf beveel of toegestaan is, gaan verder as net die geval van Genesis $9: 6$. Ortodokse gereformeerdes huldig 'n communis opinio dat die tien gebode 'n blywende betekenis het as norma normans vir die hedendaagse wetgewing. $\mathrm{Al}$ die gebooie is foro conscientiae na hul aard en strekking bindend binne die kerk. Die owerheid kan hul substansieel aanvaar ,om ons lewe te reël in alle eerbaarheid tot eer van God volgens Sy wil' (art. 25 N.G.B.). Die vasstelling van die positiewe reg en ook die vorm van die straf behoort afhanklik te wees van die toestand en behoeftes van die staat en die menslike samelewing.

\section{Die strafmaat en regterlike diskresie}

Dit lyk in stryd met die Bybelse openbaring wanneer vir ander misdade as doodslag of van direkte of indirekte lewensbedreiging vandag nog die doodstraf toegepas word. Dit kom my voor dat Lohman reg het dat lewensberowing tot beskerming van eiendom in stryd met Gods Woord is. Dit sou verder gaan as die Bybelse beginsel ,oog om oog, tand om tand'. Lohman kom ooreen met Simon van Leeuwen se opmerking dat die algemene reël is dat wanneer geen mens gesterf het nie daar ook geen doodstraf mag plaasvind nie. Van Leeuwen se pleidooi van die doodstraf as middel 
tot beveiliging van eiendom lyk hiermee in stryd.

By ontleding van Bybelse gegewens moet verskil gemaak word tussen norm en feit. Daar word menslike handelinge genoem van te swaar strawwe wat op wraak neerkom, bv. Lameg in Genesis 4 : 23. Dit het ook gebeur dat God self 'n owerheidspersoon straf omdat hy minder barmhartig was as God self (Moses in Numeri $20: 7-12$ ).

Dit lyk asof die klassiek-gereformeerde teoloë soos Calvyn ook die moderne wetgewer die diskresie wil verleen om soos in Israel gevalle van owerspel en godslastering met die dood te straf. Dit lyk vir my egter, dat die bedoeling van Christus om ook heidene tot bekering te bring (Lukas $9: 54-56$, Joh. $3: 17,12: 47$ ) beteken dat die owerheid moet oppas om nie te streng te straf nie (vgl. Sagaria $4: 6$ ).

\section{Die Suid-Afrikaanse reg en die Romeins-Hollandse basis}

Dit is opvallend dat die Mosaiese en Romeinse reg meer gevalle ken waarin misdade met die doodstraf bedreig word as die Romeins-Hollandse reg. Hugo de Groot beperk met sy verwysings na Exodus 21 : 14, Numeri 35: 16-34 en Deut. $19: 13$ die doodstraf eintlik tot die geval van moord.

Die Romeins-Hollandse reg het die doodstraf afgeskaf in geval van godslastering (Lev. $14: 13,14$ ), waarseggery en towenary (Num. $23: 23$ ) en owerspel. In Suid-Afrika het die doodstraf voorts nog verval t.o.v. kerkroof, valse munt, brandstigting, deursteek van dyke, sodomie, bestialiteit en diefstal. ${ }^{30}$

\section{Die doodstraf in die Suid-Afrikaanse wettereg}

Die doodstraf kan in Suid-Afrika net uitgespreek word in die gevalle waarin die wettereg dit toestaan of voorskryf. Die doodstraf moet opgelê word in die geval van moord sonder versagtende omstandighede. Dit kan opgelê word in ander gevalle van moord; voorts weens hoogverraad en verkragting volgens die gemene reg; sedert 1958 weer vir roof en/of huisbraak met die doel om 'n misdryf te pleeg of poging daartoe een of ander met verswarende omstandighede; sedert 1965 weer weens menseroof of kinderdiefstal; ${ }^{31}$ weens militêre verraad en ander misdrywe wat die veiligheid van die militêre magte in gevaar stel; ${ }^{32}$ sedert 1962 weens sabotasie; ${ }^{33}$ sedert 1967 weens terrorisme. ${ }^{34}$ In 1958 en 1965 was daar dus weer 'n gedeeltelike terugkeer tot die Romeins-Hollandse reg.

\section{Die motivering van die doodstraf deur Suid-Afrikaanse regters}

Hul algemene standpunt is dat by die vasstelling van 'n gepaste vonnis moet die basiese oogmerke van om d.m.v. straf af te skrik, te voorkom, te hervorm en te vergeld oorweeg word in die lig van die omstandighede van die misdadiger en die besondere omstandighede van sy daad. As doel van die straf word gestel dat ,(1) the society must be protected; (2) the punishment must be adequate 
otherwise the administration of justice may fall into disrepute and injured persons may tend to take the law into their own hands; (3) the sentence must be appropriate as a deterrent against murder for gain and for the gratification of sexual perversion".

Hieruit volg dat die howe as grond vir die doodstraf beskou: (1) afskrikking; (2) beveiliging van die gemeenskap; ${ }^{30}$ (3) handhawing van die gesag en die openbare orde en van die standaarde van ons beskawing; ${ }^{37}$ en (4) vergelding. Dit is kenlik nie net 'n willekeurige volgorde nie, maar 'n voorkeursorde. Ook wanneer daar geen lewensberowing is nie, soos in geval van verkragting, soek die howe hul motivering vir oplegging van die doodstraf kenlik eerder in afskrikking as in vergelding. ${ }^{38} \mathrm{Na}$ my opinie kan die doodstraf ook in hierdie gevalle as vergelding beskou word indien die omstandighede van die misdaad ' $n$ ernstige aantasting of bedreiging van die liggaam of die gees van die slagoffer inhou. Tereg is opgemerk: „Dit is waar dat ons Appèlhof al die leer verkondig het dat afskrikking die hoofdoel van die straf is, en daarvoor ook steun by ons ou skrywers gekry het, maar ons meen tog dat afskrikking 'n oorweging is, waarmee daar versigtig te werk gegaan moet word. Afskrikkingstrawwe met hulle aanhangsels van openbare teregstellings en brandmerking dateer uit die donkerste dae van die strafpleging. Afskrikking regverdig nie 'n straf wat buite verhouding is met die misdaad wat gepleeg is nie". ${ }^{30}$

\section{Is die howe aan hierdie motivering gebind asof dit wet is?}

Die Engelse regstoepassing het in Suid-Afrika baie sterk invloed gehad. Tennyson het van sy vaderland, Engeland, gesê:

A land of settled government,

$A$ land of old and just renown,

Where freedom broadens slowly down

From precedent to precedent.

In ons S.A. howe pleit advokate daarom volgens Engelse patroon baie op presedente asof presedente $\mathrm{krag}$ van wet het. Ons regters het die eed afgelê, dat hul reg sal laat geskied ooreenkomstig die reg en gebruike van die Republiek (art. 10 (2), Wet op die Hooggeregshof 59 van 1959). Volgens die Romeins-Hollandse reg as deel van die Republiek se reg is die regter aan die wet gebonde; nie aan sy eie vroeëre foutiewe beslissings of aan die uitsprake van ander regters nie.40 Die howe behoort dus die wet te gehoorsaam.4i Regters wat onwettelik iemand ter dood veroordeel, is aan doodslag skuldig.42 Daar is immers geen mag in die wêreld wat nie misbruik kan word nie. ${ }^{43}$

Die presedente (of stare decisis-leer) wat algemeen deur die regters aanvaar word, hou egter in dat hul gebind is aan die ratio decidendi van vroeëre beslissings van hoër howe. Die Appèlhof het egter vryheid ten opsigte van eie beslissings. ${ }^{44} \mathrm{Na}$ my opinie gaan dit seker te ver indien die wettelike diskresie van die hof om te straf deur die presedenteleer ter syde gestel of ingeperk sou word. 
Die een regter mag die ander regter in die uitoefening van sy diskresie nie bind nie, want daar bestaan nie so 'n reël in ons reg nie. ' $n$ Uitsondering kom voor indien diskresie uitgeoefen is in stryd met voorskrifte of beginsels van die reg. Net so min beskou ek ons regters gebind aan teologiese opvattings van Simon van Leeuwen, Hugo de Groot en andere. Hulle was volgens die destydse reg ook nie bevoegd om hul opinies tot wet te verhef nie. Die persoonlike insig en opvatting van regsgeleerdes en regter kan krag van oortuiging hê, maar nooit $\mathrm{krag}$ van wet nie.

In die uitoefening van diskresie kan 'n regter hom gebonde voel aan sy gewete en godsdiens, waarvoor regsgrond gevind word in art. 2 van ons Grondwet: Die volk van die Republiek van SuidAfrika erken die oppergesag en leiding van die Almagtige God. Hierdie reël hou nie in dat ons howe aan die goddelike reg regstreeks gebind is nie, maar beklemtoon wel die vryheid van die regter en andere owerheidspersone om die wet volgens hul Christelike opvatting toe te pas. ${ }^{45}$ Dit sou kon inhou dat vergelding as eerste in plaas van laaste grond vir straf beskou word. Skrywer kon nie vasstel of 'n Suid-Afrikaanse regter hom al ooit by die oplegging van die doodstraf op 'n Skrifwoord beroep het nie, behalwe in die geval van die Transvaalse Volksraad in 1853, wat hom beroep het op Genesis $9: 6 .^{40}$

\section{Konklusies}

Ten opsigte van die geldende Suid-Afrikaanse reg beperk ek my tot die volgende konklusies:

(1) Die wetsbepaling dat moord sonder versagtende omstandighede met die dood gestraf behoort te word, vind steun in Genesis 9: 6 en die verdere Bybelse openbaring.

(2) Die bedreiging met die doodstraf van misdrywe wat direk of indirek 'n aantasting of ernstige bedreiging van die lewe van mense en van die menslike samelewing inhou, met inbegrip van die veiligheid van die staat, is geregverdig volgens die leer van die Skrif.

(3) Die doodstraf behoort slegs opgelê te kan word in gevalle van aantasting of ernstige bedreiging van die liggaam of gees van 'n mens of van die menslike samelewing. Soos die wet nou lui gaan dit skynbaar verder as die Bybelse vergeldingsleer. In die belang van die regsekerheid lyk 'n wettelike voorskrif van hierdie strekking gewens.

Dr. L. Roeleveld, Durban.

1 Sien my studie: Capital punishment: a retentionist's view en die literatuuropgawe in Speculum Juris 71-2, Volume 7, bls. 25-41, Faculty of Law, University of Fort Hare.

2 Brian O. Johanson: Capital Punishment, in: Tydskrif vir Hedendaagse Romeins-Hollandse Reg, 1971, bls. 350-361. 
3 Dit is ook die geval by Karl Barth: Church Dogmatics, Volume III, The doctrine of Creation, Part 4, 1961, Edinburgh, bls. 437-450.

4 Sprächliche Erwägungen zum Gebot ,Du sollst nicht töten' in: Theologische Zeitschrift, herausgegeben von der Theologischen Fakultät der Universität Basel, 1. Jahrgang, Heft 2, Augustus 1945. Sien ook Lexicon in veteris testamenti libros, edidit Ludwig Koehler, Leiden, E. J. Brill, 1958, bls. 242, 507-508, 907 .

5 Report of the Church and Nation Committee of the Presbyterian Church of South-Africa, 1969, vermeld op bls. 37-38 van die brosjure: The church and the death penalty, Peter Randall, 1970.

6 Vgl. C. Trimp: Geen rabbijnenschool in: De Reformatie van 9 Oktober 1971.

7 Volgens 'n berig in die Nederlands Dagblad van November 1969 het die generale sinode van die (vrygemaakte) Gereformeerde Kerke in Nederland op 5 November 1969 die volgende uitgespreek:

1. dat die beklemtoning van die eenheid en ondeelbaarheid van die mosaiese wet nimmer deur middel van 'n beroep op die vervulling van die wet in Christus tekort mag doen aan wat die Heilige Skrif sé omtrent die blywende geldigheid van die wet in Rom. $3: 31,7: 22,8: 4$ en 1 Tim. $1: 8$.

2. dat nog die onderwys van Christus wat die wet in sy ware diepte en sin geleer het Matt. $5: 17-48,12: 1-8,19: 1-12$, Ef. $6: 1-9$, Openb. $12: 17,14: 12$, nog die wegneem van die gebruik van baie bepalinge van die wet (o.a. van die besnydenis, offerdiens, feesdae; kyk bv. Hand. $15: 28-29$, Gal. 5 : 2, 3, Kol. 2 : 11, Hebr. $7: 10-18$, art. 25 Nederlandse Geloofsbelydenis) die einde beteken van die wet, veral van die tien gebooie as positiewe, en dus ook vir die nuwe testamentiese bedeling bindende wet, met inbegrip van die sabbatsgebod, die $7 \mathrm{e}, 8 \mathrm{e}, 9 \mathrm{e}$ en $10 \mathrm{e}$ gebod. Kyk Rom. $7: 7,13: 8-10$ in verband met Deut. $6: 5$ en Lev. $19: 18$. Kyk ook Matt. $19: 17-19,22: 37-40$, Lukas $10: 26-28$, Gal. $5: 14$, Ef. $6: 2,3$, Jak. $2: 11$.

3. dat art. 25 van die Nederlandse Geloofsbelydenis wel sê ,dat die seremonies en sinnebeelde van die wet opgehou het met die koms van Christus, en dat aan alle skaduwees 'n einde gekom het, sodat die gebruik daarvan onder die Christene afgeskaf moet word', maar dat hiermee nie gesê word, dat veral die wet van die tien gebooie as positiewe wet sy tyd gehad het nie; wat ook strydig sou wees met wat die belydenis elders leer in Sondag 33, vr. 91, Sondag 34-44, veral vr. 115.

4. dat die spreek van die Nuwe Testament oor die vryheid van die wet en van die vloek van die wet in Rom. $7: 1-6$, Gal. $3: 13$ geen betrekking het op ' $n$ wysiging in die geldigheid van die wet nie, dog van 'n wysiging in die posisie van die gelowige, wat deur Christus vrygekoop is van die vloek van die wet; wat ook daaruit blyk, dat die wet as reèl van dankbaarheid ons nie minder uitdruklik en kragtig voorgehou word as onder die ou verbond nie. Kyk Matt. $5: 17$, Hebr. $8: 10$ in verband met Jeremia $31: 33$, Jak. $2: 8-12$.

5. dat vir die belydenis omtrent die wet van die Here as kenbron van ons ellende geen goeie plek oorbly nie, wanneer mens van hierdie wet nie erken, dat dit as positiewe wet ook in die Nieu-Testamentiese bedeling nog gelding het nie. Kyk Rom. $3: 20,7: 17-26$. 
Voorts K. Schilder: Heidelbergsche Catechismus, deel I, bls. 72-81, Goes 1947: Die wet wat by Sinai afgekondig is, is in wese niks anders as die lewenswet wat God aan die mense in die paradys gegee het nie, maar sy vorm is na plek en tyd veranderlik. L. Doekes het in sy rede by die rektoraatsoordrag in Kampen op 8 Desember 1960 teenoor die ontkenning van die blywende normatiewe karakter van die Dekaloog deur Emil Brun. ner, P. Althaus en W. Joest, hom o.a. op Calvyn beroep.

8 Josef Bohatec: Calvin und das Recht, 1934, Graz, bls. 11, 13, 40, 41, 43, $46,100,103,106,113,114,116$.

9 Institusie, Boek IV, XX, 10.

10 Ds. C. Vonk: De Voorzeide Leer, Deel IIIb, De Nederlandse Geloofsbelijdenis, Barendrecht 1956, bls. $550-666$ oor art. 36. Vgl. ook: In die Skriflig, Oktober 1969, bls. $1-64$ en Desember 1971, bls. 46-60.

11 Die in aant. 5 vermelde rapport stel: It is worthwile noting here that the Reformed Confessions do not specifically discuss capital punishment, but only the role of the State in using force and threatening punishment in general. They interpret Romans 13 in a general way, in terms of 1 Petr. 2 : 14 (24 Articles App. IV. 1. Conf. Scot. XXIV, Westm. Conf. XXIII, Heid. Cat. 105, Conf. Belg. XXXVI).

12 Sien ds. C. Vonk (aant. 10), Deel IIIb, bls. 23-29 omtrent sy marteldood.

13 Ds. C. Vonk (aant. 10), bls. 601-606. Omtrent die lewe van Guido de Brès, kyk bls. 28-50 van J. F. Munneke: Het historisch fundament der kerk, Goes 1972.

14 Grontlicke Ondemijsinghe teghen allerleve dwalinghen der Wederdooperen deses tijts inde Nederlanden, Franeker, 1609, deel II, bls. 425-435.

15 As iemand jou op jou regterwang slaan, draai ook die ander een na hom toe. K. Schilder: Christus in Zijn lijden, deel II, bls. $42-74$ en Schriftoverdenkingen, III, bls. 523-525 lees hierdie woord in verband met Johannes $18: 22,23$. Christus is die priester in die orde van Melgisedek. Hy word in die Hof van die Joodse Hoë Raad, waar die hoëpriester 'n afstammeling van Levi is en regter, aangekla. 'n Dienaar van die hoëpriester slaan uit eie beweging Christus op sy wang en Kajafas laat hlerdie minagting van die hof toe. Kyk Prediker $3: 16$. Christus neem die wet nie in eie hande nie, maar vra toepassing van die wet volgens Sy leer. Anders sou die Hoë Raad strafbaar wees met die helse vuur, Matt. 5 : 22. Dit stry nie met die Bergrede om toepassing van die OuTestamentiese wet te vra nie.

16 Pro of contra de doodstraf, Rotterdam 1946, bls. 25-32.

17 K. Schilder: Schriftoverdenkingen 1956, deel I, bls. 37-38, sê dat Christus aan Petrus die swaardgebruik verbied, omdat Hyself aan die Sanhedrin wil verwyt dat dit in 'n geestelike saak nie met redenering, betoog of geestelik ondersoek nie, maar met swaarde en stokke wil beslis. Petrus sou anders dieselfde doen en hierdie argument aan Christus ontneem. Eers wil Hy die regsvraag laat beslis, daarna die magsvraag. Deel II, bls. 61-67: Die swaard hou in die reg van die sterkste. Maar so 'n reg bestaan daar nie. Die Skrif roep om die sterkte van die reg. Die swaarde van Petrus en Kajafas is dus nie beslissend nie.

18 Hollandse Consultatiën III, $1688 \mathrm{XC}, 4$, bls. 282: ,gelijck oock andere judiciele Wetten van het Oude Testament/de Christenen niet en obligeren/als 
doot ende geevanesceert zijnde ten tijde van Gratie'.

Hollandse Consultatiën III, 1688, CXLIX, bls. 429.

20 Hollandse Consultatiën IV, 1660, bls. 526-546.

21 Boek II en XX. Gebruik is gemaak van die Engelse vertaling van Francis W. Kelsey, reprinted New York-London 1964.

22 Inleidinge tot de Hollandse Regtsgeleertheid III, 32, 7.

23 Rooms-Hollands Regt, Amsterdam 1708, boek IV.

24 Proces-Crimineel en Regtelyke Bewering over het voorval of en hoe verre in Lijfstraffelijke saken de wil voor de daad mag opgenomen, en gestraft werden, Leiden 1725.

25 The jurisprudence of my time (Heedendaegse Rechtsgeleertheyt), Volume II, Durban 1939, Boek VI, 23, bls. 464-465.

26 Jhr. A. F. de Savornin Lohman, Verzamelde Opstellen, Staatsrecht, Tweede deel, 's-Gravenhage 1921, bls. 226-243.

27 S. Greijdanus: Schriftbeginselen ter Schriftverldaring, Kampen 1946.

28 K. Schilder: Wat is de hemel?, Kampen 1935, bls. 257-262.

29 Die woorde wat daar tussen staan, want God het die mens na sy beeld gemaak' slaan waarskynlik nie net op Genesis $9: 6$ nie, maar op die gehele Skrifgedeelte, en moontlik ook op die herskepping in die toekoms. Sien K. Schilder: Heidelbergsche Catechismus, deel I, Goes 1947, bls. 296-298.

30 Simon van Leeuwen: Rooms-Hollandse Regt, Boek IV, 33, 5: 34, 6: 37, 7.

31 Art. 330 Strafproseswet 56 van 1955.

32 Soos opgesom en omskryf in art. 4 Eerste Bylae Verdedigingswet 44 van 1957.

33 Soos omskryf in art. 21 Algemene Regswysigingswet 76 van 1962.

34 Soos omskryf in art. 2 en art. 3 Terroristewet 83 van 1967.

35 Staat v. Matthee, 1971 (3) SA 773-774.

36 Die aanbeveling van twee Durbanse hoogleraars in die Nataller van 6 Nov. 1970 om doodstraf moontlik te maak vir die belhamels in dwelmmiddelsmokkelary wat deur hul bedrywighede 'n hele gemeenskap ruïneer, gaan na my opinie te ver.

37 Volgens Rapport van 8 Oktober 1972 se regter Hiemstra dat 'n mens gevalle kan vermenigvuldig waar 'n daad so diep ingedruis het teen die standaarde van ons beskawing dat algehele verwydering van die dader al was wat die ontwikkelde regsgevoel kan verdedig.

38 R. v. Robert 1957 (4) SA 265 A in the case of a sex murder: Death penalty to protect the public and as a deterrent. Volgens Daily News van 27 Mei 1971 se regter Henning dat die doodvonnis net in die ernstigste gevalle van verkragting opgele moet word en as ernstige waarskuwing moet dien vir ander seksuele aanranding, in die besonder wanneer jong kinders daarin betrokke is. In casu is die doodstraf opgele aan 'n Kleurling van 31 jaar met 15 vorige veroordelings, wat 'n dogter van $2 \$$ jaar verkrag het, waarby haar skedel gebreek is en sy ander ernstige verwondinge opgeloop het. Volgens die Daily News van 23 Febr. 1973 het regter Beyers geen doodstraf opgele in 'n verkragtingsgeval omdat die doodstraf nooit 'n reël hier moet word nie en dit daartoe sou kon lei dat verkragters hul slagoffers sou doodmaak om aan die gevolge van hul daad te ontkom. Hy hoop dat die gevangenisstraf van 16 jaar as afskrikking sal dien. 
Volgens Daily News van 17 Mei 1973 het regter Theron 'n man ter dood veroordeel wat vier jong meisies verkrag het nadat hy hul weerstand gebreek het deur 'n gevaarlike mes teen hul kele te druk en gedreig het om hul dood te maak in geval van verset.

39 J. C. de Wet en H. L. Swanepoel: Die Suid-Afrikaanse Strafreg, 1960, 191-192.

40 Simon van Leeuwen beredeneer dit in die Voorrede van sy Proces Crimineel (sien aantekening 24) op grond van die Romeinse reg. Hy wys hoe skadelik dit dikwels is om net op die gesag van 'n ander te vertrou. Hy het meermale ondervind dat 'n opinie wat lank geldig was deur 'n noukeurig ondersoek van die wette weer verander is en mens hoef daarvoor nooit skaam te wees nie. Pomponius het as 87-jarige nog geroem in die spreuk dat al staan iemand reeds met een been in die graf, hy nog nie skaam sou wees om te wil leer nie. Dit is verkeerd om die mag van die regter so ver te trek dat hy mag oordeel sonder om aan die wet gebonde te wees. Dit is 'n bekende reël dat ons skaam moet wees om iets sonder wet of regsbewys te spreek of the skryf. Die keisers self was onderwerp aan die reg wat hul self gemaak het. Die Romeinse reg sê al geniet 'n regterlike oordeel watter groot aansien, nogtans kan dit die rede of die wet self nie verander nie. Daar moet nie volgens voorbeelde nie maar volgens die wet reg gedoen word. Quamvis enim rerum saepius judicatarum non vilis sit authoritas 1. 34.1.38 ff de legib. non usque adeo tamen valitura est, ut aut rationem vincat aut legem 1.2 . Cod. quae sit longa consuetudo: et non exemplis, sed legibuss judicandum 1.13. Cod. de sententiis et interloct. om. jud.

Cornelis van Bynkershoek, president van die Hof van Holland, stel dit in Quaestionum juris publici libri duo, translation 1930, To the reader, bls. 6 soos volg; ,Even our supreme court, which pronounces its judgements as if divinely inspired, though it is bound by oath to observe the laws, nevertheless frequently alters its decisions on one and the same purely legal question, even where there has been no change in the membership; for it may be that members who were not so wise before, have gained in wisdom, or a previous decision may be forgotten in a question which is properly defended on both sides, or different laws may seem of paramount importance at different times, or there may be other considerations that I need not mention'.

Blykens Nederlands Juristenblad 1971 het die president van die ,Hoge Raad der Nederlanden' beklemtoon dat die Hoge Raad nie wette maak nie en dat sy beslissings oor regsvrae soms te veel verband hou met die saak wat beslis moes word. Advokate moet daarom nie skaam wees om op billikheids- en regsgronde aan die Hoge Raad te versoek om 'n van vroeëre beslissings afwykende standpunt in te neem nie.

41 Hollandse Consultatiën, III, 617, ,Provisien by de Hoven verleent tegen de Privilegien van de Steden of Resolutie van de Staten zyn nul ende is niemand gehouden de selve te obedieren. Item, wat te verwachten is, soo de Hove van Justitie niet en obedieren de bevelen van de Heeren Staten'.

42 Hugo de Groot: Inleiding tot de Hollandse Regtsgeleerdheid, Boek III, 33, met beroep deur Groenewegen op Dict. 1, 29 par pen. d. fin C. Sien ook slot van III, 37 .

43 Hollandse Consultatiën, III, 514, 73. 
44 Sien omtrent hierdie leerstuk o.a. H. R. Hahlo en Ellison Kahn: The South-African legal system and its background, 1968, 214-293.

45 Sien my studie „Die voorrede en begin van ons Grondwet” in: Huldigingsbundel Daniel Pont, 1970, 295-325.

46 Kyk H. Hettema: De Nederlandse stam in Zuid-Afrika, Zutphen 1949, 114. 